\title{
Evaluation of School Environmental Programs Regarding the Objectives for the Environmentally Literate Students, of Heraklion, Greece Prefecture
}

\author{
Maria Kalathaki ${ }^{1, *}$ \\ ${ }^{1}$ School Advisor for Science Teachers in Secondary Education, Regional Educational Directorates of Crete, Crete, \\ Greece \\ *Correspondence: School Advisor for Science Teachers in Secondary Education, Regional Educational Directorates \\ of Crete, Knossos Avenue 6, Postal Code 71306, Heraklion, Crete, Greece. Tel: 30-281-075-1469. E-mail: \\ kalathakimaria.edu@gmail.com
}

Received: August 8, 2014

Accepted: December 27, 2014 Online Published: January 6, 2015

doi:10.5430/wje.v5n1p40

URL: http://dx.doi.org/10.5430/wje.v5n1p40

\begin{abstract}
This evaluation research concerns the aims and objectives for creating the future environmentally literate citizen through the environmental programs (PEEs) of Secondary Education of Heraklion prefecture, Crete, Greece. An evaluation tool applied on the application forms and the final reports of the programs, in order to asses how sustainable they were in the initial planning, whether they satisfy the principles and objectives of Education for the Sustainable Development (ESD), if they aimed to culture values, abilities, skills in accordance to the UNESCO and European Community Strategies. The goal of cultivating skill of social action and social interventions which is of capital importance in ESD programs, seems to be designed and realized moderately in the studied programs. The effectiveness and the benefits of the materialization of the programs, are higher than the assessed by the statistical analysis, as there were some mismatches between the application forms and the final reports of the school environmental programs, where achieved goals, indeed adequately, which had not been included in the initial planning.
\end{abstract}

Keywords: education for the sustainable development; school educational programs; environmentally literate students; educational goals for active citizens

\section{Introduction}

The main purpose of Education for the Sustainable Development (ESD) is to create active citizens who will be capable of systematic and comprehensive consideration of social, economic, cultural, political constituents of an environmental issue, to participate and act, according to the Strategy of the United Nations Economic Commission for Europe (UNECE, 2005). ESD is a policy and environmental literacy of essential core for the future of the planet, since engaged with the natural resources and the production, their distribution and redistribution, power and decision-making, social organization, culture and ideology (Flogaiti, 2006). The purpose of the Programs of Education for the Sustainable Development (ESDP) is to create citizens who respect the rules in a planned future and promote changes in attitudes towards the environment at individual and social level (UNECE, 2005). The development of active citizens, by ESDPs, concerns the active, creative, critical, global citizen, who, with democratic accountability and individual responsibility, will be able to combine theoretical knowledge with practical and innovative ideas, to develop initiatives, to manage risks, to overcome obstacles (Hernandez \& Monroe, 2000; Huckle, 2006a). The cultivation of environmentally literate citizens requires a different education in school years that will be continuing and into adulthood, that will introduce early the students into issues related to the situation of the local and global environment, dealing with everyday life as possibilities for intervention and change for better quality of life, without harming the environment (Huckle, 2009; Scott \& Gough, 2003). This requires reorientation of the educational process within the foundation of ESD in formal and non-formal education and fostering lifelong learning processes (Sterling, 1996). We urgently need a shared vision of core values to provide the base of morality of the new world that is emerging (Earth Charter, 2000). ESD has the fundamental relationship with the values because 
seeks the dignity and respect to the human rights throughout the world, the social and economic justice for all and for the future generations, the respect to the diversity of terrestrial ecosystems and the commitment to a culture of tolerance and peace, locally and globally (Huckle, 2006b).

The main objective of the ESDPs is to educate students in the process of democratic participation and decision making. Students learn to work with vision and scenarios based onto communication, critical and creative thinking, with partnerships and collaborations in social action, seeking alternative ways for the development and the change, setting criteria for their choices comparing short and long term effects of their decisions and alternative choices (UNECE, 2005; DfES, 2006a; McKeown, 2002; Breiting, Mayer \& Mogensen, 2005). The circular GME106553/C7/13.10.2006 of the Greek Ministry of Education established the conceptual framework of design and implementation of the school Programs of Environmental Education (PEE), regarding the environment and the sustainability.

This research carried out in the PEEs which were materialized during the school year 2005-2006 in the secondary schools of Heraklion Crete prefecture, in order to asses how sustainability penetrated their design, whether the established goals satisfied the principles and the objectives of ESD.

\section{Method}

The Research Method was Case Study and Content Analysis/Literature Analysis of archival material of the PEEs (Cohen \& Manion, 1994; Iosifidis, 2003). The research sample consisted of archival material of the submitted PEEs in Secondary Education of Heraklion during the school year 2005-2006, consisting of 22 Application Forms (AFs) with corresponding 22 Final Reports (FRs), in printed and electronic form, and texts written by some of the coordinators of the programs. Eight (8) of these programs had been evaluated and had been approved for funding by Aegean University. Thereafter, an additional group of 14 programs selected, those had first in line submitted to the Secretariat. In the sample there are represented small and large schools of rural and urban areas of Heraklion prefecture. All the AFs of the programs had the same pattern (title, method, activities, evaluation, schedule, budget, names of participating students and teachers), conforming to the PEEs template of Greek Ministry of Education. The FRs hadn't a template, they were collections of a variety produced materials in the Programs, mainly containing texts from newspapers, magazines and internet, interviews, texts of students and teachers their experiences and the benefits of their participation in the program, also songs, music, photos, videos. Many of them made extensive references to the subject of the program by giving many highlights from the literature search. For triangulation, the used multiple sources of data collection, such as AFs, FRs, texts of teachers and students, other surveys in Greek and international Environmental Education, were combined with qualitative and quantitative analysis(Bell, 1997; Vergidis, 1999).

For the purpose of this research largely realised the Evaluation Tool for the Environmental Programs of Greek Secondary Education through the prism of Education for the Sustainable Development (Kalathaki, 2013). This evaluation tool applied to the archival material of the PEEs, by taking into consideration the FRs, in order to asses if the objectives that had set in the AFs achieved during the implementation of the Programs. The criteria correspond to the research subjects and questions based on the Greek and International literature (UNECE, 2005; European Union, 2006; UN, 2002; Mogensen and Mayer, 2005; DfES, 2006a\&b; Flogaiti 2006; Skoullos 2007; Circular of the Greek Ministry YA106553/C7/13.10.2006). The Evaluation Tool applied, following the formulated research subjects and questions: A. development of knowledge in terms of the issues: a. ecology, b. sustainable development, B. cultivation of values and behaviours: a. how are they cultivated? b. what kind of values promoted? C. developing skills: students practice in a. problem solving, b. seeking and findings ways of communication, c. developing partnership, d. developing collaborations e. cultivating critical thinking, f. choosing social action and social interventions for the cultivation of active citizen, D. requirements of establishing lifelong learning: do the design and implemented programs give rise to the students the need for lifelong learning?

The organization of the research categories focused on addressing the basic questions, that constitute the main purpose of the research, and are related to the investigation of the established educational goals, from the point of view of ESD. The base unit of recording was the phrase and the paragraph. It was preferred not to be encoded by using a known software for the classification of the recording unit in general categories of meaning, since, it was not the same recording unit for the classification of the variety and diverse, hardly distinguished data. The scoring criteria was 0-4 in five-point scale, based on the contents of the archive data. 0 : no evidence to satisfy the criterion. 1: limited, weak satisfaction, 2: moderate, 3: substantial, strong satisfaction, 4: the design and implementation of the program were very good grade, educational actions considered adequate, relevant and effective, the program was 
designed along the directions of ESD and significantly promoted the principles of ESD. Analogue scale and indices developed the team of experts of the UNECE for assessing the state of the UNECE Strategy for ESD (UNECE, 2005). Careful readings of AFs and FRs were repeatedly underlined the points and holding notes, since relied on them the answer of the research questions and the scoring of the criteria (Bell, 1997; Iosifidis, 2003). All recorded notices were taken into account in the export of the final score for each criterion. The scoring of each criterion reveals the degree of harmonization with the principles, dimensions, scopes and objectives of ESD in the design and implementation of each studied Program.

Thereafter, the scoring criteria entered into special databases in Excel, separately for AFs and the FRs. The statistical analysis of the data performed separately on the 22 AFs and 22 FRs and quantified by using the specialized software Statistical Package for Social Science (SPSS). Frequencies (N) and \% relative frequencies (percentages) exported per each criterion and per research question, in each grade level. Tables of results, of each criterion, in each cell, contains the $\%$ relative frequencies (in the horizontal row) and frequencies (in the vertical column) for grades $0,1,2,3,4$. For each research question, there is information, in which, each cell contains frequencies and percentages for the average received grade by the $22 \mathrm{AFs}$ and $22 \mathrm{FRs}$ of the programs. The average grade of each question was calculated as the average of the scores of the query criteria and then, rounded to the nearest whole number to go out rates. In essence, the 0 represents the interval $[0,0.5), 1$ the interval $[0.5,1.5), 2$ the interval $[1.5,2.5), 3$ the interval $[2,5,3.5)$ and 4 the interval $[3.5,4)$.

\section{Results and Discussion}

The Tbilisi Declaration (UNESCO, 1977) defined five categories of objectives that need to get individuals and groups by EE: awareness and sensitivity towards the environment and environmental problems, knowledge and understanding of the environment and environmental problems, attitude of caring towards the environment, skills that identify and solve environmental problems, active participation in solving environmental problems. The educational objectives of PEE, in accordance with the Charter of Belgrade and the UNECE Strategy for ESD (UNECE, 2005), should refer to knowledge, understanding, attitudes, skills, values and behaviours of the students. Schools demonstrate the possibilities of the creative merging of educational policies with the Earth Charter as an ethical foundation (Savelava et al, 2010). Particular reference should be made to the targeted capacity building and evaluation of the participatory action.

\subsection{Culture of Environmental Knowledge}

Table 1. Aims and Objectives of the Programs of Education for Sustainable Development (ESDP) for Creating Environmentally Literate Citizen. Frequencies and \% Relative Frequencies of the scores per criterion of the research object IIA concerning the Cultivation of knowledge on Ecology and Sustainable Development (research questions IIAa and IIAb). Scale Score $0-4$

\begin{tabular}{|c|c|c|c|c|c|c|c|c|c|c|c|c|c|}
\hline & \multicolumn{5}{|c|}{ FINAL REPORTS (FR) $(\mathrm{n}=22)$} & \multicolumn{5}{|c|}{ APPLICATION FORMS (AF) $(n=22)$} \\
\hline & & & & 0 & 1 & 2 & 3 & 4 & 0 & 1 & 2 & 3 & 4 \\
\hline \multirow{6}{*}{ II. } & \multirow{6}{*}{ A. } & & 1 & 2 & 2 & 6 & 6 & 6 & 4 & 5 & 7 & 3 & 3 \\
\hline & & & & 9,1 & 9,1 & 27,3 & 27,3 & 27,3 & 18,2 & 22,7 & 31,8 & 13,6 & 13,6 \\
\hline & & a. & 2 & 3 & 5 & 8 & 5 & 1 & 0 & 1 & 10 & 4 & 7 \\
\hline & & & & 13,6 & 22,7 & 36,4 & 22,7 & 4,5 & 0,0 & 4,5 & 45,5 & 18,2 & 31,8 \\
\hline & & b. & 1 & 0 & 3 & 11 & 6 & 2 & 0 & 0 & 10 & 6 & 6 \\
\hline & & & & 0,0 & 13,6 & 50,0 & 27,3 & 9,1 & 0,0 & 0,0 & 45,5 & 27,3 & 27,3 \\
\hline
\end{tabular}

As published by the Department of Education and Skills of Great Britain, all young people should have regular and meaningful learning experiences, well focused and enjoyable for the world beyond the classrooms as an essential part of learning and personal development, in accordance to their ages, abilities and circumstances (DfES, 2006b). The environmental literacy assessment, in 2015 by the Program for International Student Assessment (PISA), will be discussed in relation to science performance, environmental attitudes, intention to act and in relation to background variables, such as socioeconomic and immigrant status (Paden, 2012). Table 1 illustrates the frequencies and percentages of the scores of criteria used in the evaluation of the objectives of developing knowledge of students of ecology and SD. As assumed from the criteria scoring, the PEE cultured knowledge of ecology, but not very extensively. In the FR of the program A1, two students wrote: "I learned how is nature away from the exhaust gases of the city", "I found out new plants and new mountains" and "I learned so many things for my place". Students participating in ESDPs acquire specific thematic knowledge about local plants, animals, nutrition, by using national 
databases of species (Gough, 2005). The 2008 report of the English School Inspectorate noted that schools were more successful in developing pupils' understanding of local rather than global issues (Scott, 2010). A good level of knowledge offered by the studied Programs on biotic and a-biotic factors of ecosystems, as a percentage of 54.6\% (N $=12$ ) got rated 3 and 4 (Table 1), contrary to the study of the mechanisms and interactions of environmental factors, objectives that were not specifically mentioned. In the objectives listed in the program B1, is mentioned "emphasis will be given to impressive features, phenomena, interactions of plant and animal organisms in ecosystems, which will motivate students and sharpen their observation and judgment ... Linking biodiversity and functioning of the protection of the environment". Because there is no single response to environmental issues, ESD due to its nature, helps the students to impart by themselves the concept of sustainability.

Key theme of the ESD are social relationships and their mechanisms, because they are combined with economic and cultural factors associated with ecological problems, offering a comprehensive knowledge of the environment in the broadest sense (Tillbury \& Cooke, 2005; Skoullos, 2007). Such types of relationships seem sought at PEEs, as shown by the relatively good scores of AFs and FRs. The $77.3 \%$ of FRs $(\mathrm{N}=17)$ took grades 2 and 3 (Table 1), the score of AFs was lightly higher. The PEEs also seem not to be closely related to the objectives of cultivation of knowledge by the Natural Sciences, fact that was identified also in two else Greek researches of Flogaiti \& Liarakou (2003) and Tamoutseli (2006). Opposed, the rating of the criterion of cultivation of social relations and mechanisms, promoted strongly by the ESD, showed a more significant priority in the design, which in fact, supported quite well in the implementation of programs. The required knowledge for the sustainable literate citizen might well be developed or 'tested' in the context of linked curriculum and community development projects (action research), in an open discussion of greening the economical applied systems (Huckle, 2009). Integration of green Sciences, not only of Chemistry, as Mageswary et al (2011) referred, permits the courses to be interdisciplinary and teach higher-order cognitive skills, from the algorithmic imparting type knowledge to higher order cognitive skill learning (Zooler 2004).

\subsection{Culture of Values and Behaviours towards the Environment}

The ESD promotes common values of people, countries, communities, such as responsibility, solidarity, equality, respect to the dependency of future generations from the past and current, from the environment (UNECE, 2005). The research focused on ethical values, the values which are understood as 'what is believed to be good and of primary importance to human civilization, and that often articulated as ideal, rather than the moral values, the values which enforce judgement by defining the right from the wrong, the good behaviour from the bad, as Anello (2008) says. There was not found enough evidence in the archival material to reveal if the PEEs designed to cultivate the ESD values. This does not mean that the studied Programs not aimed at reinforcing the values of democracy, solidarity, responsibility, autonomy, tolerance, beauty, ecological sustainability at various levels (Flogaiti, 2006). Probably, recording detailed references was considered of limited significance. Analogue ascertainment made Drakonaki (2006) in a survey of PEEs of Secondary Education of Lassithi prefecture of Crete, where also not mentioned teaching strategies of values, although as she says, the promotion of various values outweighs the categories of research objectives.

In the FR of the program A1, one student writes about the benefits of his participation in the environmental team that "the program taught us the mutual assistance, brought the students closer and made us realize that if we are all joined, we can manage everything", "the duty to the future generations to preserve biodiversity and quality of life on the earth ... understanding of multiple value of the organisms and the ecosystems for human survival in the past, present and future: economic value of exploitation of nature for nutrition, industry, pharmaceutical etc, moral value retention and value of existence of species of flora and fauna and their habitats" (FR of program B7). There were not references to the promotion of social justice (European Union, 2006), although there were reports of "awareness and taking up of personal responsibilities in many environmental issues, such as awareness and responsibility in water consumption" (AF of program B7). In this case, match the words of Cretan writer Nikos Kazantzakis "To love the responsibility. To say I ought, I only have the duty to save the Earth. If I do not save, it will be my fault" (Anemogiannis, 2000).

The cultivation of the aesthetical criterion in students was among the priorities of many Programs. Students in the Program A1 wrote that "will have the opportunity of experiencing, through their senses, the fragrance of flowers and nature, photographing nature..." According to the Earth Charter (2000), respect and caring of life, in a sustainable community, consists in ensuring the Earth's of generosity and beauty for present and future generations. 
Table 2. Aims and Objectives of the Programs of Education for Sustainable Development (ESDP) for Creating Environmentally Literate Citizen, regarding the teaching skills and establishing Conditions for Lifelong Learning (Research objects C and D respectively). Frequencies and \% Relative Frequencies of the scores per criterion of the research questions on teaching skills of problem solving (LIFA), communication (IIGv) of partnership (IIGg), partnerships (IIGd), the critical spirit (IIGe) and Social Action (IIGst). Score Scale 0-4

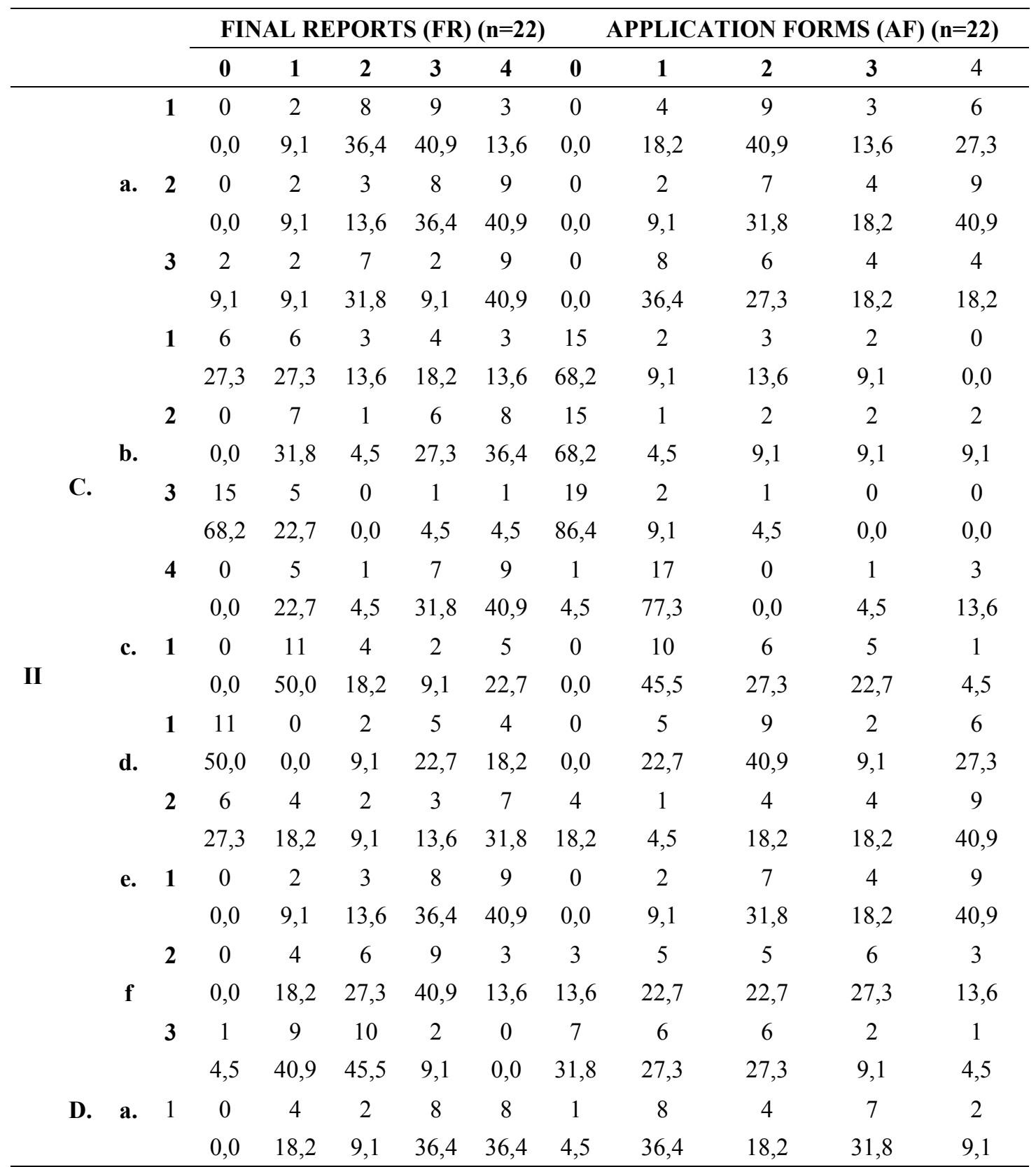

\subsection{Cultivation of Skills}

Besides the knowledge and the commitment to Sustainable Development vision and principles, several critical skills can help young people to become effective promoters of the Earth Charter in their own lifestyles, in the transformation of their communities. These skills are social, are the skills of communication and collaboration, which concern critical analysis of the situations, practical research and identification of existing problems, which shape up prospective ideas, develop initiatives, search for partners and professional experts, build up fruitful cooperation and multicultural interaction in the face of adversarial situations: unresolved conflicts, ethnic tensions, lack of resources (Savelava et al, 2010). The cultivation of ESD skills, as target of the studied PEEs, generally, was reported incompletely in AFs, mainly inferred from the content analysis of FRs, which had, respectively higher 
scores than AFs. Rather omitted to be referred to AFs, in contrast with the skills of problem solving and developing partnerships that were referred as well designed (Table 3). $45.4 \%(\mathrm{~N}=10)$ of programs were rated 3 and 4 to the three criteria of problem solving and $59.1 \%(\mathrm{~N}=13)$ of programs in development cooperation. In AFs there were no reports to indicate that the cultivation of the communication skill was priority of the Program design, but finally carried out, at a relatively good level, during the implementation of the Programs, since the FRs took scores of 2 and 3 at a rate $68.2 \%(\mathrm{~N}=15)$.

Table 3. Frequencies and \% Relative Frequencies of the scores per criterion of the total number of criteria on Aims and Objectives of the research objects IIA about Culture of Knowledge-IIA and Culture of Skills-IIC. The research questions listed in cultivation of knowledge of Ecology (IIAa), of Communication Skills (IICb) collaborations (IICd) and social action / intervention (IICf). Score Scale 0-4

\begin{tabular}{|c|c|c|c|c|c|c|c|c|c|c|c|c|}
\hline & & \multicolumn{5}{|c|}{ FINAL REPORTS (FR) $(n=22)$} & \multicolumn{5}{|c|}{ APPLICATION FORMS (AF) $(n=22)$} \\
\hline & & & $\mathbf{0}$ & 1 & 2 & 3 & 4 & $\mathbf{0}$ & 1 & 2 & 3 & 4 \\
\hline \multirow{10}{*}{ II } & $\mathbf{A}$ & $\mathbf{a}$ & 0 & 6 & 4 & 9 & 3 & 0 & 4 & 10 & 2 & 6 \\
\hline & & & 0,0 & 27,3 & 18,2 & 40,9 & 13,6 & 0,0 & 18,2 & 45,5 & 9,1 & 27,3 \\
\hline & & $\mathbf{a}$ & 0 & 2 & 6 & 10 & 4 & 0 & 2 & 10 & 7 & 3 \\
\hline & & & 0,0 & 9,1 & 27,3 & 45,5 & 18,2 & 0,0 & 9,1 & 45,5 & 31,8 & 13,6 \\
\hline & & b & 2 & 5 & 9 & 6 & 0 & 10 & 8 & 4 & 0 & 0 \\
\hline & \multirow[t]{5}{*}{ C } & & 9,1 & 22,7 & 40,9 & 27,3 & 0,0 & 45,5 & 36,4 & 18,2 & 0,0 & 0,0 \\
\hline & & d & 4 & 3 & 8 & 4 & 3 & 0 & 3 & 6 & 7 & 6 \\
\hline & & & 18,2 & 13,6 & 36,4 & 18,2 & 13,6 & 0,0 & 13,6 & 27,3 & 31,8 & 27,3 \\
\hline & & f & 0 & 4 & 8 & 9 & 1 & 1 & 8 & 7 & 4 & 2 \\
\hline & & & 0,0 & 18,2 & 36,4 & 40,9 & 4,5 & 4,5 & 36,4 & 31,8 & 18,2 & 9,1 \\
\hline
\end{tabular}

\subsection{Cultivation of Problem Solving Skills}

Cultivation of problem solving skill appears to be cultivating at a good level (Tables 2 and 3). In PEEs, students are getting a taste of the complexity of the environmental issues (Table 2) because $77.3 \%(\mathrm{~N}=17)$ of FRs scored 2 and 3 and $13.6 \%(\mathrm{~N}=3)$ was rated excellent. As often referred in the FRs, after understanding the components of the environmental problem, follows the formulation of proposals and solutions. The wording of alternative solutions builds sustainable and further deeper the potentiality and probability of tackling modern environmental issues (Jensen, 2005). Central axis of a sustainable school, according to the national ESD context of Great Britain is cultivation of critical thinking, development of the ability of problem solving and formulation of alternative solutions (DfES, 2006b). The FRs took very good scores to this criterion. Good, even slightly lower, were also the rates of the AFs (Table 2), as $77.3 \%(\mathrm{~N}=17)$ of FRs scored grade 3 and 4 , the corresponding percentage in the AFs was $59.1 \%$ $(\mathrm{N}=13)$. The main objective of ESDP is to educate students in the process of democratic participation in deciding the actions which can affect the problems, engage in comparing short and long term results of alternatives options and decisions taken (Breiting et al, 2005; Gough, (2005). The target of skill-decision development not mentioned often in AFs, as $36.4 \%(\mathrm{~N}=8)$ of them got grade 3 or 4 , it seems to be cultivated, since the percentage in FRs was significantly higher $(50 \%, \mathrm{~N}=11)$. In the educational practice, the ESDP should visibly strengthen youth participation in decision-making processes, in demonstrating students' ability to make the difference and to contribute to the solution of relevant problems in their communities (Savelava, 2010). Novices would benefit from an insistence on an adequate and sufficient comprehension of the situation prior to the actual planning of learning activities, as the learning environment will include sub-tasks and information that will helps learners to develop the ability to conceptualize a problem prior to its solution (Mercier, 2012).

\subsection{Cultivation of Communication}

In AFs there were no reports to indicate that the Programs intend to engage the rest school community in the implementation. It happened in a few Programs, where questionnaires were distributed, interviewed or invited schoolmates, parents, teachers, local authorities in the presentation of the Program results. The relatively low scores of AFs and FRs in this criterion is shown in Table 2, where, 54.6\% $(\mathrm{N}=12)$ of FRs rated 0 and 1 . The corresponding rate of AFs was significantly much higher $72.7 \%(\mathrm{~N}=16)$. It seems that, although the cultivation of communication skills included in the design of the Programs, as target, no promotion took place during the materialization.

Schools that carry out ESDPs operate together with the local community, promote and encourage mutual cooperation, bring real issues into the curriculum through the involvement of community groups (Scott, 2007). It is important to determine the roles, rights and obligations of each member of the school community who participates in the process of "greening" the school (Posch, 1999). The results of research on the involvement of local communities from those 
of involvement of the school community. In some Programs, such as those of group A, even they do not refer to the AFs the intention to involve the local community, finally they do it. In FRs, the highest percentage $(63.6 \%, \mathrm{~N}=14)$ assigned on both upper grading scales on getting information from the local community. In AFs, the corresponding percentage was significantly lower $(31.8 \%, \mathrm{~N}=7)$. And, indicating that this target is eventually achieved even it hadn't taken in consideration during the design of the Program.

Media are not exploited by PEEs as shows the extremely low rating of this criterion. The $68.2 \%(\mathrm{~N}=15)$ of the FRs did not indicate evidence to satisfy this criterion (zero score) as well as $86.4 \%(\mathrm{~N}=19)$ of AF. Of course, there were exceptions in those Programs where students became journalists interviewing locals and experts, as the Program A8, where distributed 800 questionnaires to students of Heraklion city. Media production and circulation emerge new dimensions of literacy studies. Chen \& Wu (2010) proposes a new framework for further explanation of the development of media literacy that is from functionality to criticality and from consumption to presumption. International networking workshops, seminars and international conferences are an important part of the school year and ways to bring Australian national program managers, teachers and teacher trainers together for professional development, to share experiences in the procedure of the school greening (Henderson \& Tilbury, 2004). In addition, summer camps and Eco-schools Award ceremonies are ways to bring students together at the international level. In AFs there were not listed participations to conferences, meetings, events, etc, but there were a few in the FRs, as in the programs A1, A2, A5, B3 and B6 who participated to 7th Student Conference at Heraklion. This is due to the fact that at the beginning of the school year, when AFs prepared, have not, yet, announced meetings and conferences that will take place during the whole school year. This explains the large difference in the scores of this criterion in AFs and FRs (Table 2).

For the criterion of negotiations and compromise, there were not references to AFs and FRs to satisfy it. Of course, this does not mean that, because teachers do not specifically mention these two concepts in the AFs and FRs, they not promote them, implicitly, during the implementation of the Programs. Furthermore, students are in constant negotiation with the subject of the Program, the sources of knowledge, with the coordinator-teachers, with external collaborators. They interact with them, make plans, customized to demands and availability, by making choices, giving and receiving information and materials.

\subsection{Cultivation of Critical and Creative Thinking}

Vare and Scott (2007) interface the building capacity in critical thinking as a way to look at ideas and explore dilemmas and inherent contradictions in sustainable living. In relatively high percentages was promoted the development of students' critical thinking by PEEs, as it comes out of the scores of AFs and FRs, $40,9 \%(\mathrm{~N}=9)$ rated with 4 (Table 2). Concurrent object was the cultivation of creative thinking of students (Table 2), since were developed various activities to promote creative thinking and imagination of the students. In AF of program B11 is written "To develop students skills ... creative imagination", "creative expression of students (theatre Karagiozis show, poetry, literature ... This will lead to their creative expression to write a play text and dramatize ... From our previous experience in programs, it appears that, during the implementation process, students are inspired and driven to creative expressions. This leads into a theatre a poem or painting".

\subsection{Cultivation of Partnership}

According to UNESCO Decade of ESD, partnership is the strategic key for the development of the Education because brings innovation and change, creates a shared vision for jointly achieving sustainability (UNECE, 2005). The PEEs seems to promote the school partnership in a relatively low degree (Table 2), confirming Flogaiti's (2006) aspect, that, partnership in education is hardly feasible. The only reference for collaboration between schools was between the environmental teams of programs B10 and B12, which actually mentioned unilaterally only by B10 and without details. There are many regional, national and international thematic networks of EE which operate as large communities supporting methodologically and scientifically the school-members. Although networks are the means for collaborative action which provide opportunities spreading relations and exchanging of good practices, the participation in them was not in the priority in the PEEs. In the AFs of group A Programs were reports of involvement of schools in national environmental networks but in the FRs there was no evidence about this type of participation. Half of FRs $(\mathrm{N}=11)$ scored 1 and only $\mathrm{N}=5(22.7 \%)$ took the highest score 4 . The score of AFs was analogue, as the percentages were $45.5 \%(\mathrm{~N}=10) \kappa \alpha$ l $4.5 \%(\mathrm{~N}=1)$. The mentioned networks were only "Sustainable City", "The schoolyard", "The ports of Greece", even there were many networks coordinated by the Environmental Education Centres.

Also, there were no reports about participation of the student councils in the implementation of the programs and their exploitation in actions and social interventions developed within the programs. Only in one program, in the AF and not in the FR, mentioned cooperation with the student council of the school. 


\subsection{Cultivation of Cooperation}

Developing partnerships is a key axis of design and structuring of the ESDPs. In partnership with the local community, the school involves the community as a source of teaching and learning, serves as a centre of action that stimulates the local sustainable development, acts as the core of society opening to needs and proposals (Mogensen \& Mayer, 2005; Breiting et al, 2005). The two criteria, jointly, scored relatively higher both at AFs than FRs (Table 3). They had higher frequencies $54.6 \%(\mathrm{~N}=12)$ in the FRs and $59.1 \%(\mathrm{~N}=13)$ respectively in AFs in classes rating 2 and 3. In the studied Programs, is described a variety of collaborations with experts and local people. It was recorded $31.8 \%(\mathrm{~N}=7)$ of FR was rated 4 and $40.9 \%(\mathrm{~N}=9)$ of AF. However, a significant percentage of FRs $(27.3 \%$, $\mathrm{N}=6)$ got a zero score, with corresponding of AF $18.2 \%(\mathrm{~N}=4)$. The most common collaborations were developed with cultural associations $(\mathrm{N}=21)$, government agencies $(\mathrm{N}=13)$, local municipal authorities $(\mathrm{N}=12)$, museums $(\mathrm{N}$ $=10)$, Environmental Centres ( $\mathrm{N}=7)$, Associations of Parents $(\mathrm{N}=6)$ and with experts, scientists and citizens who had been chosen to advise students on the Program topics $(\mathrm{N}=5)$. Roussou (2007), in a research on EE showed that only $48 \%$ of Primary school teachers develop relationships with social bodies, $81 \%$ of Gymnasiums and $70 \%$ of Lyceums. However, it is impressive the limited references in AFs and FRs to-partnerships with parents (6 reports in total 86, that $6.98 \%$ ). In Cyprus, also, was recorded inability to establish new roles and forms of parental involvement in school events and identify difficulties adopting new relationships and networks of cooperation between teachers, parents and students (Georgiou, 1996; Symeou, 2002). According to the Great Britain Strategy of ESD (DfEs, 2006a\&b), the parental involvement in ESDP is demanded since enables the exploitation of their time, energy and experience.

\subsection{Cultivation of Social Action and Social Interventions of the Active Citizen}

The ESD focuses on civil society, on clarification of values, on developing collective consciousness and actions to solve problems, to improve the quality of life (Tilbury \& Cooke, 2005). The action and participation have educational value because they function as ways of becoming known practices of a democratic society (Breiting et al, 2005). As Mahatma Gandhi said, an ounce of action is more worth than a ton of teaching. The books offer the knowledge, but the action translates it into understanding. Environmentally literate citizen is that person who, having the necessary of environmental knowledge, forms attitudes and behaviours towards the environment and believes that is life duty to participate actively in the formulation of strategies and policies on issues relating to the environment (Rawls, 2004). Based on this approach, the studied PEEs do not seem to promote enough this type of citizen. They, moderately, cultivate the skill of Social Action, Social Interventions for Creating Active Citizens (Table 3) since $77.3 \%(\mathrm{~N}=13)$ of FRs got grade 2 and 3, and AFs had slightly lower performance in this criterion $(50,0 \%, \mathrm{~N}=11)$. The cultivation of eco-management skill is poorly promoted in most of the Programs, since the interest is centred only in familiarizing the region, knowing the special features of the problems and not in undertaking initiatives to affect and solve the problems. Of course, there were some Programs that designed and modified satisfactorily the school area and suggested to the municipalities ideas for improvements of their villages. In this criterion, $40.9 \%(\mathrm{~N}=9)$ of FRs got grade 3 and $13.6 \%(\mathrm{~N}=3)$ got grade 4 . Respectively, $27.3 \%(\mathrm{~N}=6)$ of AFs took grade 3 and $13.6 \%(\mathrm{~N}=3)$ took 4 . In A5 program, based on suggestions collected from the questionnaires, shaped the schoolyard "we made a rock garden with herbs ... we started reforming by planting flower plants...".

The Local Agenda 21 was not mentioned by any PEEs, although some principles of Agenda listed in the objectives of many Programs. Most of these references limited to the first level of implementation of the objectives, concerning the need of introducing students to the local environment, not going ahead to an action plan by undertaking initiatives in the local environments, extending them to national and global level.

3.10 Establishment of Requirements for Lifelong Learning through Intergenerational Cooperation with Agencies, Organizations, Local Groups, Parents

The general objective of the Lifelong Learning Programmes of EE (EP, 2006) is to contribute to the development of the community as an advanced knowledge-based society with sustainable economic development, for more and better jobs and greater social cohesion, while ensuring good protection of the environment for the future generations. In particular, these Programs it aims to foster interchange, cooperation and mobility between education and training systems within the community, in order to become a world quality reference. The ESD is treated as a lifelong process starting at early childhood, continues through higher education and adult education, eventually surpassing the limits of formal education (European Commission, 2006). Since learning takes place as much as we undertake various roles in our lives, ESD should be considered as a process that extends through out our whole lives. In each educational program, the foundation of lifelong learning carried out, except the educational process in formal education, through the interactions with teachers, parents, other students, community representatives, generally through contact and cooperation with persons linked to the educational policy (Mylonakou-Keke, 2006). Many PEEs had several 
indications for foundation of lifelong learning and this is why this criterion scored relatively high. The $72.8 \%(\mathrm{~N}=$ 16) of FRs scored higher on both the grading scale and the AFs' percentage was $40.9 \%(\mathrm{~N}=9)$.

\section{Conclusions}

The research aimed to assess how circumstantial was the design and structuring of the school PEEs of Heraklion prefecture in order to educate the future environmentally literate citizens. For this purpose, an evaluation tool applied on the AFs and the FRs of the Programs, to asses how sustainable they were in the initial planning, whether they satisfy the principles and objectives of ESD, if they aimed to culture values, abilities, and skills in accordance to the UNESCO and European Community Strategies. The objectives of the studied PEEs generally referred to knowledge, understanding, skills, values and attitudes of learners. The PEEs provided ecological knowledge at a relatively good level but not in the study of the mechanisms and interactions of environmental factors. The study of social relations and their mechanisms promoted to better level, since, in many Programs, the social dimension of the SD matched well to the environment. The cultivation of many skills of the active citizen was promoted in sufficient level, but not all of them satisfactorily. Exception was the skill of problem solving and of partnership which mentioned frequently in AFs and FRs. Students had the chance of realizing the complexity of the environmental issues. The programs materialized mainly out of the classrooms, but without significant interchange between the school and the local community. Participation in conferences, workshops, round tables, social events were limited. Networking and partnership grew modestly, only in some schools, while, in good level developed partnerships among students, teachers and external partners chosen to assist the Programs.

The goal of cultivating skill of social action and social interventions for creating the active citizen, which is of capital importance in ESD, seems to be designed and realized moderately in the studied PEEs. The extremely low score of this criterion is alarming for the promotion of ESD through PEEs in Cretan Secondary Education. Encouraging is the clearly higher criterion of eco-management skill. The creating of conditions for Lifelong Learning seems to be quite well established in the Programs. Working with stakeholders on specific themes, with local groups and organizations, according to the topics of the Programs, and developing of a generational cooperation, help students to consolidate the need and assign value to the continuous personal development and improvement, in order to be competent to the needs of modern societies.

Generally speaking, the effectiveness and the benefits of the materialization of the school environmental programs are higher than the assessed by the statistical analysis, as there were some mismatches between the AFs and the FRs of the school environmental programs, where achieved goals, indeed adequately, which had not included in the initial planning. For example, while not designed getting information and work with the local community, eventually it was developed. Also, although the cultivation of communication skills included in the design of the programs, there were not promotion during the materialization.

Particular emphasis should be given to the preparation of goals for developing skills of communication and policy interventions, as they are of high importance and priority in ESD but of minor in the studied PEEs. If goals and objectives had defined and formulated clearer, more thoroughly and specifically, the providing ESD by the PEEs, according to UNECE (2005), could be more significant and effective. Regarding teaching of values, there were not clear references to both types of the investigated archival material to what values are promoted and in which way. It is necessary, also, to clarify the values that should promote each Program, in accordance to the subject, and to be given special attention in the field of culture of values, as culturing values is potentially hopeful for a vent from the economic crisis of nowadays.

In order to achieve the goals of ESD, not only Programs must be improved to serve better the principles of ESD, but also the schools must reform their overall goals and orientations, being more sustainable operating as core model of the local communities. The PEEs can, also, give the directions of a more sustainable school for the teachers, students, parents, local community, by supporting the innovation and the creativity, offering a critical vision on the environmental problems. Teachers and principals clearly understood culture in a different way after participating in school-based culturally responsive evaluation. However, more theoretical work and field studies will need to be conducted to further assess being culturally responsive in evaluation (Ryan et al, 2007). The schools deterioration makes imperative the need of redefining the environmental education policy for the implementation more effective PEEs in changing attitudes and configuring values and attitudes to students-tomorrow's global citizens. The new curricula must be designed on the Report of the International Commission on the Education for the Twenty-first Century and incorporate the Treasure within Learning: to know, to do, to live together, to exist (Delor, 1996). 


\section{References}

Anello, E. (2008). A Framework for Good Governance in the Public Pharmaceutical Sector: Working draft for field testing and revision, October 2008. Switzerland: World Health Organisation

Anemogiannis G. (2000). N. Kazantzakis, the way towards eternity, 2nd Edition of N. Kazantzakis Museum. Varvaroi. Heraklion, Crete.

Bell J. (1997). Methodological Design of Pedagogical and Social Research. Gutenberg Publications, Athens.

Breiting S., Mayer M., \& Mogensen F. (2005). Quality Criteria for ESD-Schools, Guidelines to enhance the quality of Education for Sustainable Development, SEED, Socrates/Comenius Project, Austria. Retrieved from http://www.seed-eu.net

Chen T., \& Wu J. WU. (2010). Deconstructing New Media: From computer literacy to new media literacy. Retrieved 20th December 2012 from http://www.iiis.org/CDs2010/CD2010SCI/EISTA_2010/PapersPdf/EA508KR.pdf

Cohen, L., \& Manion, L. (1994). Research Methods in Education (4th ed.). London: Routledge.

Delor J. (1996). Learning: the treasure within. Report to UNESCO of the International Commission on the Education for the Twenty-first Century, UNESCO.

DfES. (2006a). Sustainable Schools for pupils, communities and the environment - Government response to the consultation on the sustainable schools strategy. Retrieved from http://publications.teachernet.gov.uk/default.aspx?PageFunction=productdetails\&PageMode=publications\&Pro ductId=DFES-04294-2006

DfES. (2006b). Learning Out-side the Classroom, Manifesto. Published by the Department for Education and Skills. Retrieved from http://www.oric.Org.au/conferences

Drakonaki X. (2006). Environmental Education in the Schools of Lasithi prefecture, $2^{\text {nd }}$ Congress of School environmental Programs, Athens 15-17 December 2006.

Earth Charter. (2000). The Earth Charter, Values and Principles to Foster a Sustainable Future. Retrieved from http://www.earthcharterinaction.org/content/pages/Read-the-Charter.html

European Union (2006). Reconsideration of the Strategy for the Sustainable Development. European Council, Brussels 26 of June. Retrieved on 14-7-2007 from http://ec.europa.eu/sustainable/docs/renewed_eu_sds_el.pdf

Flogaiti E. (2006). Education for the Environment and the sustainability, publishing Greek Letters, $\left(2^{\text {nd }}\right.$ ed.). Athens.

Flogaiti \& Liarakou. (2003). Interdisciplinary in the Environmental Education: achievement or requested? Subjects in Education, 4, 17-20

Georgiou, S. N. (1996). Parental involvement in Cyprus. International Journal of Educational Research, 25(1), 33-43. http://dx.doi.org/10.1016/0883-0355(96)82040-4

Gough A. (2005). Sustainable Schools: Renovating Educational Processes. Applied Environmental Education and Communication, 4, 339-351. http://dx.doi.org/10.1080/15330150500302205

Henderson, K., \& Tilbury, D. (2004). Whole-School Approaches to Sustainability: An International Review of Sustainable School Programs. Report Prepared by the Australian Research Institute in Education for Sustainability (ARIES) for the Department of the Environment and Heritage, Australian Government. ISBN1864089792.

Hernandez O., \& Monroe M.C. (2000). Thinking about behavior, in Environmental Education and Communication for a Sustainable World. Handbook for international Participants. USA: Academy for Educational Development

Huckle J. (2006a). Ethics, values and consumer education in ESD, University Notes, Workshop 4-8 December 2006, Post Graduated Program of "Environmental Education", Aegean university, Rhodes, Greece. http://dx.doi.org/10.1080/13504620802578509

Huckle J. (2006b). Pedagogical critical method, inquiry, project work, University Notices, Workshop 4-8 December 2006, Post Graduated Program of “Environmental Education”, University of Aegean, Rhodes, Greece.

Huckle J. (2009). Consulting the UK ESD community on an ESD indicator to recommend to Government: an insight into the micro-politics of ESD. Environmental Education Research, 15(1), 1-16.

Iosifidis, T. (2003). Analysis of Qualitative Data in Social Sciences. Kritiki publishing: Athens. 
Jensen B.B. (2005). Building Capacity and Empowerment through ESD, a conference report on ESD in Esbjerg, Austrian Federal Ministry of Education, Science and Culture.

Kalathaki M. (2013). Evaluation tool for the environmental programs of Greek Secondary Education through the prism of Education for the Sustainable Development. US-China Education Review, 3(7), July 2013.

Mageswary K., Zurida I., \& Norita M. (2011). Greening a Chemistry Teaching Methods Course at the School of Educational Studies, Universiti Sains Malaysia. Journal of Education for Sustainable Development, 5, 197. http://dx.doi.org/10.1177/097340821100500210

McKeown R. (2002). Charles A. Hopkins, Regina Rizzi, Marianne Chrystalbridge, Education for Sustainable Development-Toolkit Energy. Environment and Resources Centre, University of Tennessee, USA.

Mercier J. (2012). From Laboratory to Authentic Contexts: Two Studies of Pedagogical Reasoning Across Four Levels of Expertise. World Journal of Education, 2(4), 2-19. http://dx.doi.org/10.5430/wje.v2n4p2

Mogensen F., \& Mayer M (eds) (2005). Eco-schools: trends and divergences. School Development through Environmental Education (SEED), Austria.

Mylonakou-Keke H. (2006). Modern theoretical approaches in the communication of school-family-community. Atrapos ed, Athens

Paden M. (2012). NAAEE Releases Framework for Assessing Environmental Literacy: Being Used in 2015 OECD Assessment. Journal of Education for Sustainable Development, 6, 17.

Posch P. (1999). Ecologisation of Schools and its Implications for Educational Policy. Cambridge Journal of Education, 29(3), 341-348. http://dx.doi.org/10.1080/0305764990290304

Rawls J. (2004). Political Liberalism. Metehmio ed: Athens.

Rousou S. 2007) Materialization of the optional programs in the schools of Primary and secondary education and their contribution to the professional development of the teachers. The view of the teacher. Thesis, Open University of Greece, Patra.

Ryan K., Chandler M., \& Samuels M. (2007). What should School-Based Evaluation Look Like? Studies in Educational Evaluation, 33(2007), 197-212. http://dx.doi.org/10.1016/j.stueduc.2007.07.001

Savelava S., Savelau D., \& Bakhnova Cary M. (2010). Practicing ESD at School: Integration of Formal and Nonformal Education Methods Based on the Earth Charter (Belarusian Experience). Journal of Education for Sustainable Development, 4(2), 259-269. http://dx.doi.org/10.1177/097340821000400214

Scott W. (2007). Goodfellow M. and Andrew-Power K. (editors), Raising standards: making sense of the sustainable schools agenda, Specialist Schools and Academies Trust, London.

Scott, W., \& Gough, S. (2003). Sustainable Development and Learning, Framing the issues. London, RoutledgeFalmer. http://dx.doi.org/10.4324/9780203464625

Skoullos M. (2007). Evolution of the Environmental Education toward the Education for the Sustainable development. Similarities and differences, Proceedings of the $3^{\text {rd }}$ Pan-Hellenic Congress of PEEKPE with the subject of Education for Sustainability and Environmental education: Society-Economy-Environment-Civilization, 9-11 November, Athens.

Sterling, S. (1996). Education in Change. In Huckle, J. \& Sterling, S. (eds), Education for Sustainability, Earthscan.

Symeou, L. (2002). Present and future home-school relations in Cyprus: An investigation of teachers' and parents' perspectives. The School Community Journal, 2(12), 7-34.

Tamoutseli K. (2006). From the Environmental Education to the Education for the Sustainability. Journal for the Environmental Education, 36, 4-7.

Tilbury D., \& Cooke K. (2005). A National Review of Environmental Education and its Contribution to Sustainability in Australia: Frameworks for Sustainability. Australian Research Institute in Education for Sustainability, Camberra: Australia.

UNESCO (1997). Declaration of the International conference in Thessalonik. Suggestions for achieving sustainability (1997). Environment and Society: Education and awareness of citizens for the Sustainability, organized by UNESCO and the Greek Government. Retrieved on 14-6-2007 from http://www.ekke.gr/estia/Unesco/results.htm 
UNECE (2005). Strategy of UNECE for the Education for the Sustaiinable Development, High level meeting of the ministers of Environment and Education, Vilnius, 17-18 of March

Vare P., \& Scott W. (2007). Learning for a Change: Exploring the Relationship between Education and Sustainable Development. Journal of Education for Sustainable Development, 1(2), 191-198. http://dx.doi.org/10.1177/097340820700100209

Vergidis D. (1999). Design and Structure of Programs for Adult Education. Adult Education, Vol 3. Greek Open University, Patra.

Zooler, U. (2004). Chemistry and Environmental Education. Chemistry Education: Research and Practice, 5(2), 95-97. 